\title{
The Outcome of Gastroesophageal Reflux Disease after Eradication Therapy of Helicobacter Pylori
}

\author{
SAAD ELDEEN M. EL SHEREF, M.D.* and HESHAM S. ABD AL SAMIE, M.D.** \\ The Departments of Internal Medicine* and Clinical Pathology**, Faculty of Medicine, Al-Azhar University, New Dmaitta
}

\begin{abstract}
Background: Helicobacter pylori is a nice of social pathogen that has sick about half of the world's populace.

It continues to be a major health problem worldwide, causing considerable morbidity and mortality due to peptic ulcer disease and gastric cancer.

Aim of Study: The goal of our research was to investigate the relationship between H.pylori eradication and development of GERD.
\end{abstract}

Subjects and Methods: A prospective research recruited 189 individuals who triedhelpful for $\mathrm{H}$. pylori and followed them for a year.

To identify H. pylori, at least one rapid test, C-urea breath test, and histology were performed, with at least one of them being positive. To establish eradication from $\mathrm{H}$. pylori, all tests were performed.

The gastric mucosa is evaluated endoscopically to identify stomach mucosal waste.

The severity of GERD symptoms was divided into three sorts: Minor, modest, and sever.

Six and twelve months following endoscopic assessment, symptoms were assessed.

Results: the nastyphase of the participants was $49.5 \pm 0.9$ and $55 \%$ of them were males. Among the participants there were $28 \%$ current smokers and $66.7 \%$ were non-alcoholic. Atrophic gastritis appeared among the participants with the percentage $60.3 \%$ for open atrophic gastritis. At 12 months and among who could successfully eradicated from $\mathrm{H}$. pylori infection there were 24\% developed esophagitis or symptoms. Factors statistically significant associated with GERD were age, smoking and alcohol consumption.

Conclusion: H. pylori purgefixes not cause gastroesophageal reflux illness, according to current evidence.

The endoscopic results show that effective eradication does not result in anrise in the rate of esophagitis.

Key Words: H. pylori purge - Gastroesophageal reflux disease - Reflux esophagitis.

Correspondence to: Dr. Saad Eldeen M. El Sheref, The Department of Internal Medicine, Faculty of Medicine, Al-Azhar University, New Dmaitta

\section{Introduction}

HELICOBACTER pylori is a nice of mortal pathogen that has sick about half of the world's populace.

It increases the chance of dysplasia, gastritis, peptic ulcers, and digestivetumor by causing the loss of stomach glands.

In addition, $\mathrm{H}$. pylori taint has been related to a variety of extraintestinal malignancies.

Now, the "test and treat" plan advises treating very H. pylori helpful boil and non-ulcer dyspeptic patients once a noninvasive test for $\mathrm{H}$. pylori is did [1].

Gastroesophageal reflux illness (GERD) is a complicated illness that occurs when stomach contents reflux into the oesophagus, causing unpleasant symptoms and/or problems [2].

Increased stomach acid production and reduced lower esophageal sphincter pressure are also significant factors in the pathogenesis of GERD.

Because Helicobacter pylori infection reduces stomach acid production in a significant percentage of people, $\mathrm{H}$. pylori taint has been linked to the progress of GERD.

In line with earlier research, a large communitybased training of $\mathrm{H}$. pylori and GERD create that both self-described indicative GERD and endoscopically confirmed erosive GERD were contrariwiselinked with $\mathrm{H}$. pylori taint [3] .

It has also been observed that as eradication treatment has been more widely used, the decreasing frequency of $\mathrm{H}$. pylori pollution has been accompanied with a rise in the rate of GERD and associated consequences. 
As a result, $H$. pylori taint seems to be a "protective" issue for GERD, despite the fact that this theory has not ever been supported by stylish, population-based trainings [4].

Infection with Helicobacter pylori (H. pylori) is prevalent in many areas of the globe.

Because GERD is such a prevalent ailment, it's not surprising that it may coexist with $\mathrm{H}$. pylori infection.

What is the link between $\mathrm{H}$. pylori infection and the development and severity of GERD?

H. pylori seems to protect against the formation of GERD or to decrease its severity in most research; nevertheless, a few studies indicate that it may exacerbate GERD.

The following evidence may help to clarify the potential link between GERD and H. pylori [5] .

Maintenance According to current recommendations such as the Asia-Pacific Consensus on the Management of GERD and the Maastricht III Consensus Report, antisecretory medicines such as proton-pump inhibitors (PPI) are suggested for relieving symptoms and repairing erosive esophagitis patients with GERD.

However, it has been demonstrated that longterm PPI therapy for GERD changes the pattern of gastritis within the stomach and increases the risk of developing gastric atrophy and intestinal metaplasia, which may lead to gastric cancer, in the presence of $\mathrm{H}$. pylori infection [6].

Furthermore, chronic H. pylori taint has been linked to the progress of an esophageal squamous cell carcinoma subtype.

As a result, despite the supposed "protective effect" for GERD, eradicating H. pylori taint in individuals with GERD may provide antotalprofit [7]

Many clinical investigations and systematic reviews have looked into the link between $\mathrm{H}$. pylori eradication and GERD [8].

The effects of $H$. pylori eradication on the development of GERD remain unclear, and the results of these published reviews are contradictory.

As a consequence, we performed a metaanalysis based on published randomised controlled trials (RCTs) to investigate the relationship between H. pylori eradication and the onset of GERD [9]
As a result, the goal of this research was to look at the link between $\mathrm{H}$. pylori eradication and GERD outcomes.

\section{Subjects and Methods}

\section{Patients:}

A prospective research was carried out from September 2019 to September 2020 at endoscopic unit of Internal Medicine Department New Damitta Hospital, Faculty of Medicine, Azhar University Egypt. Enrolled patients ranged in age from 20 to 70 years old and underwent to endoscopic evaluation and GERD categorization according to the LOS Anglos classification. Patients were excluded on the basis of the following criteria (1) H. pylorinegative, (2) upper GI haemorrhage, (3) esophageal or gastric varices, (4) esophageal or pyloric stenosis, (5) previous gastrectomy, (6) H. pylori eradication, (7) presence of tumour at the gastroesophagea junction or pylorus leading to outlet obstruction (8) Taking an $\mathrm{H} 2$ receptor blocker or proton pump inhibitor (PPI) for at least 1 month in the past or present, (9) alcohol or drug abuse, and (10) pregnancy.

All participants signed a written informed consent form.

\section{Questionnaires:}

Patients who consented to take part in the research completed forms about GERD signs at the start, six months later, and a year later.

We included questions on common reflux symptoms such as heartburn and acid regurgitation in the questionnaire we created.

If the patients answered sure to the inquiries, they were asked moreenquiries on the intensity of their symptoms, which were classified as light, moderate, or severe.

The participants' BMI, as well as their drinking and burning habits, stood documented.

\section{Endoscopic examinations:}

The results of the surveys were hidden from the endoscopist.

After the to lerantfelt endoscopic assessment, the presence or absence of RE (regurge gastritis) was assessed.

RE was not defined as minor alterations in the squamocolumnarseam, for example muddling or hyperemic vagaries. 
Hiatal hernia is defined as a gastroesophageal junction that extends extra than $2 \mathrm{~cm}$ beyond the diaphragmatic impingement [10].

According to the endoscopic atrophic boundary, stomach mucosal wither was assessed and the atrophic form was classified into shut and exposed kinds.

Closed-type atrophic gastritis (antral predominant gastritis) was diagnosed when the atrophic border remained on the lesser curvature of the corpus, whereas open-type atrophic gastritis (pangastritis or corpus predominant gastritis) was diagnosed when the atrophic border no longer existed on the lesser curvature but extended along the anterior and posterior walls of the stomach [11].

Pepsinogens I (PGI) and II (PGII) blood levels stood measured by Pepsinogen I and Pepsinogen II EIA QUIZgears (BiohitOyj, Helsinki, Finland).

Serological atrophy was characterised as being present when PGI levels were fewer than $25 \mathrm{~g} / \mathrm{L}$ and the PGI to PGII share was less than 3 [10]

\section{Eradication of H. pylori and follow-up:}

A fast urease test, a C-urea breath test, and histology were accustomed spot $\mathrm{H}$. pylori taint.

Double surgery cases were taken since the larger curving of the form for histological confirmation, and the antrum and the samples were assessed next Giemsastain.

At smallest one help ful outcome from the a for ementioned tests indicated that $\mathrm{H}$. pylori infection was present.

Eradication treatment was given to individuals who tested positive for $\mathrm{H}$. pylori.

Full-dose PPI, 500mg clarithromycin, and 1000 $\mathrm{mg}$ amoxicillin were given twice daily for 7-14 days as a first-line treatment [12]

After at tiniest 4 weeks from the finish of purge treatment, a C-urea smellquiz or fast urease examstood conducted to validate the effectiveness of eradication therapy.

If the patient did not respond to triple treatment, bismuth-based multiplycure was started, consisting of full-dose PPI twice daily, 500mg metronidazole twice daily, $500 \mathrm{mg}$ tetracycline twice daily, and $120 \mathrm{mg}$ bismuth twice daily for 7-14 days.

After endoscopic resection, full-dose PPI was typically given for 4 weeks.
A 12-month follow-up EGD was done, and the existence of RE and $\mathrm{H}$. pylori grade was determined by the fast urease test.

\section{Statistical analysis:}

The means and standard deviations of continuous variables were given.

The two-sample $t$-test or the Mann-Whitney U test were active to liken incessant variables, depending on the supply.

All $p$-values stayed two-sided, and numericalimport was definite as $p$-values of less than 0.05 .

A generalised estimating equation using logistic regression was utilised to investigate the likelihood of RE and GERD signs.

Univariate and multivariate studies using logistic relapse study stood used to evaluate risk variables for RE and GERD symptoms.

The statistics package for social sciences software was used for all statistical studies (SPSS kind 21.0, Chicago, IL, USA).

\section{Results}

Table (1): Characteristic data of the participants $(\mathrm{N}=189)$.

\begin{tabular}{|c|c|}
\hline Items & $\mathrm{n}(\%)$ \\
\hline $\begin{array}{l}\text { Gender: } \\
\text { Male } \\
\text { Female }\end{array}$ & $\begin{array}{l}105(55.0) \\
84(45.0)\end{array}$ \\
\hline $\begin{aligned} \text { BMI: } & \\
& <25 \\
& -30 \\
& -35 \\
& >35\end{aligned}$ & $\begin{array}{l}101(53.4) \\
45(23.8) \\
33(17.5) \\
10(5.3)\end{array}$ \\
\hline $\begin{array}{l}\text { Smoking: } \\
\text { Non-smoker } \\
\text { Ex-smoker } \\
\text { Current smoker }\end{array}$ & $\begin{array}{l}96(50.8) \\
39(20.6) \\
54(28.6)\end{array}$ \\
\hline $\begin{array}{l}\text { Past history: } \\
\text { Diabetes mellitus } \\
\text { Hypertension } \\
\text { Hyperlipidemia }\end{array}$ & $\begin{array}{l}48(25.3) \\
36(19.0) \\
25(13.2)\end{array}$ \\
\hline $\begin{array}{l}\text { Alcohol consumption: } \\
\text { None } \\
\text { Past } \\
\text { Current }\end{array}$ & $\begin{array}{l}126(66.7) \\
50(26.5) \\
13(6.9)\end{array}$ \\
\hline $\begin{array}{l}\text { Atrophic gastritis: } \\
\text { None } \\
\text { Closed } \\
\text { Open }\end{array}$ & $\begin{array}{l}7(3.7) \\
68(35.9) \\
114(60.3)\end{array}$ \\
\hline & Mean $\pm \mathrm{SD}$ \\
\hline Age (years) & $49.5 \pm 0.9$ \\
\hline $\begin{array}{l}\text { Pepsinogen level: } \\
\text { Pepsinogen I ng/ml } \\
\text { Pepsinogen II ng/ml } \\
\text { Pepsinogen I/II ratio }\end{array}$ & $\begin{array}{l}75.5 \pm 25.3 \\
12.6 \pm 8.4 \\
4.9 \pm 3.6\end{array}$ \\
\hline
\end{tabular}

BMI: Body Mass Index. 
In Table (1) there were 189 subjects participated in our study aged from 20-70 years old with mean age $49.5 \pm 0.9$. Also, there were $55 \%$ of them males and $53.4 \%$ with BMI less than 25 . Half of them were non-smokers and two thirds were non-alcoholic. Among them there were $25 \%$ of the participants had DM. The prevalence of open atrophic gastritis was $60.3 \%$ and the mean of PG I level was $75.5 \pm 25.3$.

Table (2): Outcome of participants with or without $\mathrm{H}$. pylori infection.

\begin{tabular}{|c|c|c|c|c|c|c|c|}
\hline \multirow{2}{*}{ Items } & \multicolumn{3}{|c|}{ H. pylori positive } & \multicolumn{3}{|c|}{ H. pylori negative } & \multirow{2}{*}{$p$-value } \\
\hline & & mptoms & Esophagitis & $\mathrm{n}$ & Symptoms & Esophagitis & \\
\hline 6 months & 48 & $9(18.8)$ & $7(14.5)$ & 141 & $16(11.3)$ & $12(8.5)$ & $0.61 \mathbf{a}$ \\
\hline 12 months & 16 & $5(31.3)$ & 3 (18.8) & 173 & $22(12.7)$ & 20 (11.6) & $0.74 \mathrm{a}$ \\
\hline
\end{tabular}

H. pylori helicobacter pylori. a chi-square test.

In Table (2) the symptoms of GERD appear in 9 participants after 6 months among $\mathrm{H}$. pylori positive and at 12 months there were only 3 who
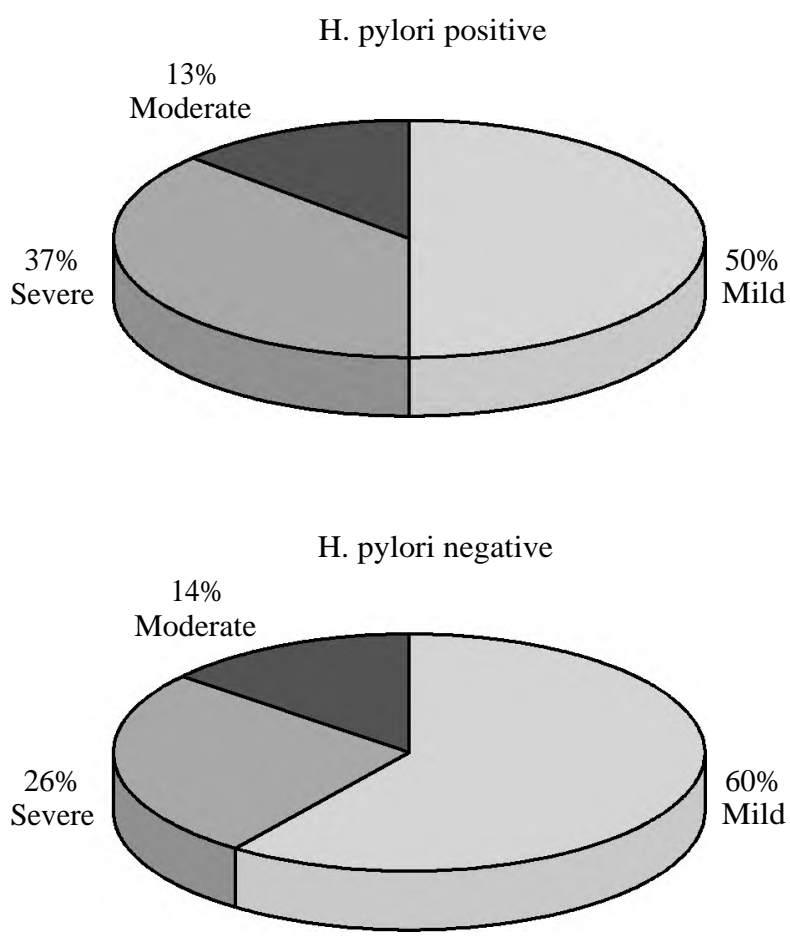

Fig. (1): Severity of GERD symptoms among H. pylori positive and eradicated.

As shown in Fig. (1) the severity of GERD symptoms at 12 months among who could successfullyeradicated from $\mathrm{H}$. pylori and those who did not. Among H. pylori negative $60 \%$ had mild symptoms comparing to $50 \%$ among $\mathrm{H}$. pylori positive. had esophagitis. Although among negative H. pylori participants there were 22 of them had symptoms of GERD after 12 months.

Table (3): Risk factors for developing GERD after H. pylori eradication $(n=42)$

\begin{tabular}{|c|c|c|}
\hline Items & Positive GERD & $p$-value \\
\hline Age & & $0.021 * \mathbf{a}$ \\
\hline \multicolumn{3}{|l|}{ Gender: } \\
\hline Male & $23(54.8)$ & $0.643 \mathbf{b}$ \\
\hline Female & $19(45.2)$ & \\
\hline \multicolumn{3}{|l|}{ BMI: } \\
\hline$<25$ & $20(47.6)$ & $0.235 \mathbf{b}$ \\
\hline-30 & $12(28.6)$ & \\
\hline-35 & $10(23.8)$ & \\
\hline \multicolumn{3}{|l|}{ Smoking: } \\
\hline Non-smoker & $5(11.9)$ & $0.002 * \mathbf{b}$ \\
\hline Ex-smoker & $12(28.6)$ & \\
\hline Current & $25(59.5)$ & \\
\hline \multicolumn{3}{|c|}{ Alcohol consumption: } \\
\hline Non & $15(35.7)$ & $0.043 * \mathbf{b}$ \\
\hline Past & $18(42.9)$ & \\
\hline Current & $9(21.4)$ & \\
\hline \multicolumn{3}{|l|}{$H T N:$} \\
\hline Yes & $32(76.2)$ & $0.128 \mathbf{b}$ \\
\hline No & $10(23.8)$ & \\
\hline \multicolumn{3}{|l|}{$D M:$} \\
\hline Yes & $27(64.3)$ & $0.405 \mathrm{~b}$ \\
\hline No & $15(35.7)$ & \\
\hline \multicolumn{3}{|l|}{ Hyperlipidemia: } \\
\hline Yes & $25(59.5)$ & $0.189 \mathbf{b}$ \\
\hline No & $17(40.5)$ & \\
\hline
\end{tabular}

a Student $t$-test.

b Chi-square test; $\mathrm{p}$ significant at $<0.005$. 
As shown in Table (3) the factors that had statistically significant association with developing GERD after eradication of $\mathrm{H}$. pylori were age, smoking and alcohol consumption.

\section{Discussion}

In individuals from industrialised nations for example Arctic America, Cowboy flick Europe, and Australia, the occurrence of $\mathrm{H}$. pylori taint is minor, while GERD and associated consequences are more common [13].

People from developing countries such as South America, Eastern Europe, Africa, China, and India, on the other hand, have a greater prevalence of $\mathrm{H}$. pylori infection, but GERD and its severity are lower.

Furthermore, owing to improved cleanliness and increased antibiotic usage, the commonness of $\mathrm{H}$. pylori taint is falling globally [14]

Gastric acid secretion may be influenced by $H$. pylori in two ways:

1- Somatostatin-secreting D-cells are destroyed in the stomach antrum due to minimal inflammation.

As a consequence, there is a lack of negative feedback on stomach acid production, which leads to an increase in parietal cell mass and hyperchlorhydria, potentially worsening GERD symptoms.

2- By killing acid-secreting parietal cells of the gastric corpus, pangastritis (more often associated with cytotoxin-associated gene A [cagA] and vacuolating cytotoxin [VacAs 1 ]-bearing strains) induces gastric atrophy and hypo- or achlorhydria. (Lupu et al., 2016).

H. pylori's discovery in the primary 1980s was a watershed moment in our knowledge of gastroduodenal illness.

Taint with this organism is a leading source of gastritis and duodenitis, as well as the popular of stomach B-cell lymphomas and duodenal ulcers.

Stomach atrophy and intestine metaplasia with hypochlorhydria result from long-term, severe inflammation, which may progress to gastric cancer.

Patients with gastric ulcers and mucosaassociated lymphoid flesh lymphoma are usually advised to have $\mathrm{H}$. pylori therapy [15] .

The goal of our research was to see whether there was a tieamid H. pylori eradication and GERD outcomes.
There was no statistically major link among $\mathrm{H}$. pylori eradication and GERD result.

More recent research suggests that eradicating H. pylori has little clinical effect on esophagitis [16-18].

There was There was no difference between the $\mathrm{H}$. and the $\mathrm{H}$. in terms of erosive esophagitis and reflux symptoms (reflux and heartburn).

In a meta-analysis that included randomised controlled trials, pylori eradication and persistent groups were found.

Another meta-analysis showed no statistically major change among endoscopic sign of esophagitis and non-endoscopic evidence of esophagitis [19]

H. pylori has stoodallied to a change of gastrointestinal complaints, including GERD.

The function of $\mathrm{H}$. pylori in the expansion of GERD is still debatable.

According to earlier research, the incidence of H. pylori taint in GERD patients assortmentssince 30-90 percent, and it seems that approximately 40 percent of GERD patients are infected with this bacteria $(20,21)$.

Furthermore, the majority of studies probing the link amid H. pylori poison and GERD have exposed no causal link.

The primary cause of esophagitis is acid interaction with the mucosa of the oesophagus [22]

In an Iranian study, the prevalence of the $\mathrm{H}$. pylori cagA gene and the coexistence of cagA and cagE were significantly higher in the control group, despite no difference in $\mathrm{H}$. pylori frequency between GERD patients and controls [23]

Tan et al. (2015) reported a significantly increased risk of GERD in patients with successful eradication compared to patients with eradication failure in a meta-analysis of RCTs and cohort studies comparing incidence rates of reflux esophagitis and reflux-related symptoms of the case versus control group [24]

According to one research, $\mathrm{H}$. pylori poison has a caring effect in GERD, and one reason for this effect is that $\mathrm{H}$. pylori taint may makestomach mucosa atrophy and decreased acid production [2]

Another theory is that $\mathrm{H}$. pylori taintrouses the vagus nerve receptors on the fundus and cardia of the stomach, increasing serum gastrin production, 
which may improve LES pressure, decrease gastric acid, and minimise reflux of gastric contents, preserving the esophageal mucosa [25].

Although 11.6 percent of individuals developed esophagitis 12 months following $\mathrm{H}$. pylori eradication and just three patients experienced GERD while still infected [26]

In a training of patients bycolonicboilillness who underwent abolition treatment, the incidence of esophagitis was estimated to be $25.8 \%$ at 3 centuries in patients who had H. pylori was effectively eliminated, compared to 12.9 percent in individuals with a persistent infection after three years [27].

In our study, age, smoking, and alcohol use were all related to the development of GERD.

In another study examining the long-term effect of $H$. pylori eradication on the prevalence of reflux esophagitis, male sex, higher BMI, habitual alcohol consumption, habitual smoking, larger diaphragmatic hiatal size, and milder gastric mucosal atrophy were found to be risk factors for reflux esophagitis. reflux esophagitis [28].

Aside from our findings, there was a strong link between GERD and smoking, with smokers having a 3.60 times greater chance of getting GERD than nonsmokers [4]

The risk was greater than in a previous research, which showed that smokers were 1.7 times more likely than nonsmokers to have reflux symptoms, indicating the significance of smoking behaviours in the growth of GERD.

Because smoking cessation improved GERD and health-related quality of life [7] it should be advised to GERD patients.

Several studies have shown that acid suppression medications should be used first-line treatment for GERD since they reduce stomach acid production [11].

In a Japanese research, the commonness and risk issues of reflux esophagitis and $\mathrm{H}$. pylori taint, as well as their association, were evaluated in 550 healthy young volunteers.

Health pupils between the ages of 22 and 30 had an higher GI endoscopy then filled out a form on GERD signs.

8.2 percent of pupils had $H$. pylori immunoglobulin $\mathrm{G}$ antibodies in their urine, and $6.9 \%$ had reflux esophagitis.
The majority of patients with reflux esophagitis tested negative for $\mathrm{H}$. pylori (92.1 percent).

Virilesex and stoutness (BMI 25) were both peril reasons for reflux esophagitis, although $H$. pylori poison did not play a role [29] .

The incidence of GERD was also greater in the heavy and obese categories than in the skinny and usualclusters, confirming earlier research that indicated BMI was important in the development of GERD [30].

The fact that bellyfatness puts weight on the belly, which promotes reflux, may explain the link between BMI and GERD.

Higher socioeconomic level has been linked to $\mathrm{BMI}$, indicating that the two may be linked in the development of GERD.

Men were more likely than women to have GERD, implying that manly patients stoodextrapossible to mature reflux esophagitis, which is dependable with prior research $[\mathbf{3 1}, 32]$.

According to our findings, GERD symptoms (heartburn and acid regurgitation) were mostly minor among those who tried helpful for $\mathrm{H}$. pylori then were subsequently cleared of it.

Mild symptoms of gastro-esophageal reflux illness were detected in 29 percent of patients with effective eradication and $8 \%$ of patients with lingering $H$. pylori taint, according to Jonaitis et al. (2018) [33]

Heart burn may improve following effective H. pylori eradication in individuals who had it before eradication treatment is given, according to another research.

In a tiny percentage of individuals, new heartburn symptoms develop [34].

Furthermore, Miftahussurur et al. (2018) discovered that the reflux esophagitis signsitemized in the GERDQ, for exampletummy aching, spewing, epigastric discomfort, sickness, and nap disruption, stood statistically extra common hip individuals with GERD than in personsminus [35].

The overall GERD questionnaire nicks were likewise linked to GERD episodes, suggesting that they may help differentiate reflux esophagitis symptoms.

Mucosal fractures, on the other hand, were discovered by endoscopy in six individuals who had not reported any symptoms in the GERD questionnaire. 
Because of the short follow-up time, the prevalence of GERD may rise after two years.

Another drawback of this research was the limited sample size.

Due to a lack of resources, we only identified GERD using endoscopy without esophageal manometry or 24-hour $\mathrm{pH}$ monitoring.

\section{Conclusion:}

The precise bondamid $\mathrm{H}$. pylori then reflux illness is quiet a mystery.

H. pylori purgefixes not cause gastro-esophageal reflux illness, according to current evidence.

The endoscopic results show that effective eradication does not result in an increase in the incidence of esophagitis.

Consumption of alcoholic beverages and smoking were both linked to the development of GERD.

However, since this is a developing field with continuous study, the future may very well change our present view point.

\section{References}

1- O'CONNOR A., FURUTA T., GISBERT J.P. and O'MORAIN C.: "Review-Treatment of Helicobacter pylori infection." Helicobacter, 25, 2020: e12743, 2020.

2- BRODERICK, RYAN C. and KARL-HERMANN FUCHS: "Symptom Spectrum in Gastroesophageal Reflux Disease". Management of Gastroesophageal Reflux Disease. Springer, Cham, 19-26, 2020.

3- JUNG C.G.: Psychology of the transference. Princeton University Press, 1-9, 2021

4- ROSANIA, ROSA: "Helicobacter pylori eradication therapy is not associated with the onset of inflammatory bowel disease: A case-control study", 2018.

5- GRANDE M., LISI G., DE SANCTIS F., GRANDE S., ESSER A., CAMPANELLI M., BALASSONE V., MILITO G. and VILLA M.: Does a relationship still exist between gastroesophageal reflux and Helicobacter pylori in patients with reflux symptoms? World J. Surg. Oncol., Dec 6; 12: 375. doi: 10.1186/1477-7819-12-375. PMID: 25479911; PMCID: PMC4396562, 2014.

6- MAHACHAI V., VILAICHONE R.K., PITTAYANON R., ROJBORWONWITAYA J., LEELAKUSOLVONG S., MANEERATTANAPORN M. and GRAHAM D. "Helicobacter pylori management in ASEAN: The Bangkok consensus report." Journal of gastroenterology and hepatology, 33.1: 37-56, 2018.

7- MILLER, ANNA K. and SCOTT M. WILLIAMS: "Helicobacter pylori infection causes both protective and deleterious effects in human health and disease." Genes \& Immunity, 1-9, 2021.

8- QIAN B., MA S., SHANG L., QIAN J. and ZHANG G.: Effects of Helicobacter pylori eradication on gastroesopha- geal reflux disease. Helicobacter, Aug. 16 (4): 255-65, 2011.

9- ZHAO S., LIN Q., RAN J., MUSA S.S., YANG G., WANG W. and WANG M.H.: Preliminary estimation of the basic reproduction number of novel coronavirus (2019-nCoV) in China, from 2019 to 2020: A data-driven analysis in the early phase of the outbreak. International journal of infectious diseases, 92: 214-217, 2020.

10- NA H.K., LEE J.H., PARK S.J., PARK H.J., KIM S.O., AHN J.Y. and JUNG H.Y.: "Effect of Helicobacter pylori eradication on reflux esophagitis and GERD symptoms after endoscopic resection of gastric neoplasm: A singlecenter prospective study." BMC Gastroenterology, 20.1: $1-7,2020$

11- ANNIBALE, BRUNO, GIANLUCA ESPOSITO and EDITH LAHNER: "A current clinical overview of atrophic gastritis." Expert review of gastroenterology \& hepatology, 14.2: 93-102, 2020.

12- LONG X., CHEN Q., YU L., LIANG X., LIU W. and LU H.: "Bismuth improves efficacy of proton-pump inhibitor clarithromycin, metronidazole triple Helicobacter pylori therapy despite a high prevalence of antimicrobial resistance." Helicobacter, 23.3: e12485, 2018.

13- XIE T., CUI X., ZHENG H., CHEN D., HE L. and JIANG B.: Metaanalysis: Eradication of Helicobacter pylori infection is associated with the development of endoscopic gastroesophageal reflux disease. Eur. J. Gastroenterol. Hepatol., 25, 2013.

14- ARMSTRONG D., BENNETT J.R., BLUM A.L., DENT J., DOMBAL F.T. and GALMICHE J.P.: The endoscopic assessment of esophagitis: A progress report on observer agreement. Gastroenterology [Internet], 111. Available from: https://doi.org/10.1053/gast.1996.v111.pm8698230, 1996.

15- SOKUCU S., OZDEN A.T., SUOGLU O.D., ELKABES B., DEMIR F. and CEVIKBAS U.: CagA positivity and its association with gastroduodenal disease in Turkish children undergoing endoscopic investigation. J Gastroenterol [Internet], 41. Available from: https://doi.org/ 10.1007/s00535-006-1788-z, 2006.

16- LEVINE A., MILO T. and BROIDE E.: Influence of Helicobacter pylori eradication on gastroesophageal reflux symptoms and epigastric pain in children and adolescents. Pediatrics [Internet], 113. Available from: https://doi.org/ 10. 1542/peds. 113.1.54, 2004.

17- FISCHBACH L.A., NORDENSTEDT H., KRAMER J.R., GANDHI S., DICK-ONUOHA S. and LEWIS A.: The association between Barrett's esophagus and Helicobacter pylori infection: A meta-analysis. Helicobacter [Internet] 17. Available from: https://doi.org/10.1111/j.15235378.2011.00931.x, 2012.

18- LAINE L. and SUGG J.: Effect of helicobacter pylori eradication on development of erosive esophagitis and gastroesophageal reflux disease symptoms: A post hoc analysis of eight double blind prospective studies. Am J Gastroenterol [Internet], 97. Available from: https://doi.org/10.1111/j.1572-0241.2002.07116.x, 2002.

19- GRANDE M., CADEDDU F., VILLA M., ATTINA G.M., MUZI M.G. and NIGRO C.: Helicobacter pylori and gastroesophageal reflux disease. World J. Surg. Oncol. 
[Internet], 6. Available from: https://doi.org/10.1186/14777819-6-74, 2008.

20- GOYAL R.K. and MCGUIGAN J.E.: Is gastrin a major determinant of basal lower esophageal sphincter pressure? A double-blind controlled study using high titer gastrin antiserum. J. Clin. Invest [Internet], 57. Available from: https://doi.org/10.1172/JCI108280, 1976.

21- WONG B.C. and KINOSHITA Y.: Systematic review on epidemiology of gastroesophageal reflux disease in Asia. Clin. Gastroenterol. Hepatol. [Internet], 4. Available from: https://doi.org/10.1016/i.cgh.2005.10.011, 2006.

22- LEE J.M., O'MORAIN C.A.: Different management for helicobacter pylori positive and negative patients with gastro-oesophageal reflux disease? Gut [Internet], 43. Available from: https://doi.org/10.1136/gut.43.2008.S14, 1998.

23- SUGIMOTO M., MURATA M., MIZUNO H., IWATA E., NAGATA N., ITOI T., et al.: Endoscopic reflux esophagitis and reflux-related symptoms after Helicobacter pylori eradication therapy: Meta-analysis. J. Clin. Med., 9 (9): 3007, 2020.

24- TAN J., WANG Y., SUN X., CUI W., GE J. and LIN L.: The effect of Helicobacter pylori eradication therapy on the development of gastroesophageal reflux disease. Am J Med Sci [Internet], 349. Available from: https://doi.org/10.1097/MAJ.0000000000000429, 2015.

25- ADACHI K., NOTSU T., MISHIRO T. and KINOSHITA Y.: Long-term effect of helicobacter pylori eradication on prevalence of reflux esophagitis. J. Gastroenterol. Hepatol. [Internet], 34. Available from: https://doi.org/ 10.1111/jgh.14730, 2019.

26- IIJIMA K., KOIKE T. and SHIMOSEGAWA T.: Reflux esophagitis triggered after Helicobacter pylori eradication: a noteworthy demerit of eradication therapy among the Japanese? Front Microbiol., 6, 2015.

27- LUPU V.V., IGNAT A., CIUBOTARIU G., CIUBARA A., MOSCALU M. and BURLEA M.: Helicobacter pylori infection and gastroesophageal reflux in children. Dis Esophagus [Internet], 29. Available from: https://doi.org/ 10. 1111 /dote. $12429,2016$.
28- TANAKA Y., SAKATA Y., HARA M., KAWAKUBO H., TSURUOKA N., YAMAMOTO K., et al.: Risk factors for Helicobacter pylori infection and endoscopic reflux esophagitis in healthy young Japanese volunteers. Intern. Med., 8616-69, 2017.

29- MINATSUKI C., YAMAMICHI N., SHIMAMOTO T., KAKIMOTO H., TAKAHASHI Y. and FUJISHIRO M.: Background factors of reflux esophagitis and non-erosive reflux disease: A cross-sectional study of 10,837 subjects in Japan. PLoS One [Internet], 8. Available from: https://doi.org/10.1371/journal.pone.0069891, 2013.

30- POLYZOS S.A., ZEGLINAS C., ARTEMAKI F., DOULBERIS M., KAZAKOS E., KATSINELOS P., et al.: Helicobacter pylori infection and esophageal adenocarcinoma: A review and a personal view. Ann. Gastroenterol., 31 (1): 8, 2018.

31- SHAVALIPOUR A., MALEKPOUR H., DABIRI H., KAZEMIAN H., ZOJAJI H. and BAHROUDI M.: Prevalence of cytotoxin-associated genes of Helicobacter pylori among Iranian GERD patients. Gastroenterol. Hepatol Bed Bench., 10, 2017.

32- KIM G.H.: It Is Time to Meet the Challenges of the Changing Epidemiology of Gastroesophageal Reflux Disease. J. Neurogastroenterol. Motil., 24 (4): 507, 2018.

33- JONAITIS L., PELLICANO R. and KUPCINSKAS L.: Helicobacter pylori and nonmalignant upper gastrointestinal diseases. Helicobacter, 23: e12522, 2018.

34- MARI A., MAHROUM N., BRAGAZZI N.L., SHALAATA M., KHOURY T., WATAD A., et al.: Demographics and clinical and endoscopic characteristics of patients with helicobacter pylori infection and gastroesophageal reflux disease: A case-control study. Gastroenterol. Res. Pract., 2019, 2019.

35- MIFTAHUSSURUR M., DOOHAN D., NUSI I.A., ADI P., REZKITHA Y.A.A., WASKITO L.A., et al.: Gastroesophageal reflux disease in an area with low Helicobacter pylori infection prevalence. PLoS One., 13 (11): e0205644, 2018. 


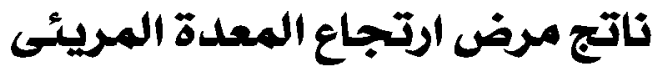

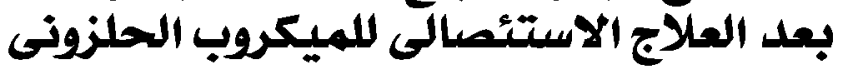

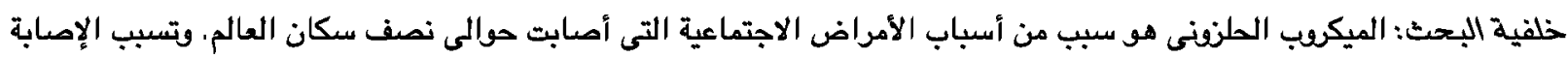

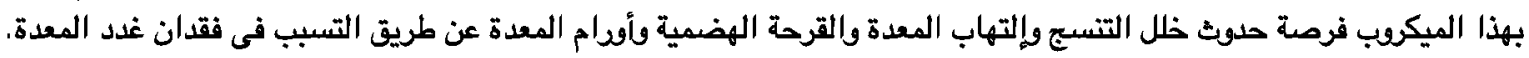
الهدف من البحث: كان الهدف من بحثنا هو معرفة ما إذا كان هنال استئمال كامل الميكرب الحلزنى ثم نتائج ارتجاع المعدة المريئى.

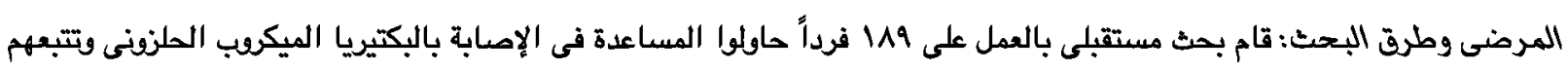

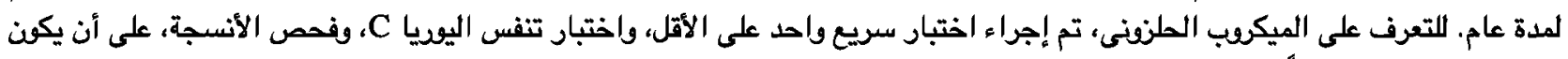
أحدهم على الأقل إيجابياً.

لإثبات استئصال بكتيريا الميكروب الحلزونى، تم إجراء جميع الاختبارات. يتم تقييم الغشاء المخاطى فى المعدة بالمنظار الهضمى العلوى لتحديد مدى الفقد فى الفشاء المخاطى المعدة. تم تقسيم شدة أعراض الارتجاع المعدى المريئى إلى ثلاثة أنقاع: طفيفة ومتوسطة وشديدة بعد ستة أشهر واثنى عشر شهراً من التقييم

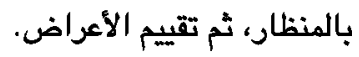

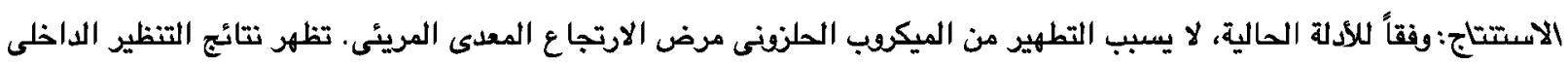
أن الاستئصال الفعال لا يؤدى إلى زيادة معدل إلتهاب المرئ. 